\title{
ENRIQUE PEZZONI
}

1926-1989

POR

\author{
SYLVIA MOLLOY \\ Yale University
}

Muchos, aun quienes apenas lo conocían, recuerdan la primera vez que lo vieron. Tanto más sus amigos, que atesoramos esa primera imagen como un talismán para alejar la evidencia de su muerte. La vitalidad, la gracia, la saludable irrespetuosidad que lo acompañaban —que más bien eran éltocaban, en un sentido material, a sus interlocutores. La presencia física de Enrique Pezzoni, su voz, sus elocuentes gestos, su risa eran manifestaciones tan fuertes y tan brillantes como las de su aguda inteligencia. Eran, acaso, la misma cosa: de él, como de Brummel, también podía decirse "el cuerpo piensa". Yo recuerdo una tarde calurosa del mes de enero, hará casi treinta años, y el comienzo de la que sería una larguísima y fraterna amistad. En un departamento de la calle Tucumán que fue, por corto tiempo, local de Sur, aprovechando la generosidad de su jefa de redacción María Luisa Bastos y la ausencia de su directora que me inspiraba terror, revisaba yo unos números atrasados de la revista cuando entró (irrumpió sería el término adecuado) Enrique Pezzoni. Habló con Bastos, me saludó con amable indiferencia, y pasó al baño. Emergió traspasado por la muy privada colonia de la ausente Victoria Ocampo: divertido ante la previsible amonestación de Bastos y encantado con su travesura, me guiñó el ojo y desapareció dejando una estela de "Heno recién cortado" de Floris y un chisporroteo de irreverencias. Fue como una ráfaga de festiva disrupción, un deslumbramiento.

¿Por qué registro esta imagen trivial, incluso frívola, de Pezzoni y no otra, por qué no me centro en lo representativo de sus excepcionales dotes intelectuales, o de su enorme aporte como crítico y como maestro, para comenzar esta compartida evocación? Pienso que no lo traiciono si llamo la atención a lo que para él fue la vida y, por consiguiente, la literatura: una práctica gozosa, no por inteligente menos total. En "La noche que en el Sur lo velaron" se pregunta Borges por las "menudas sabidurias" - un hábito, un manojo de llaves-que pierden sentido no bien desaparece su dueño. Otro tanto podría decirse de los rasgos que la posteridad, y los escribas que colaboran con ella, juzgan superficiales, insignificantes, no suficientemente serios. Esos rasgos que, lite- 
ralmente, divierten - la levedad de Pezzoni, pongamos por caso, su constante, jocosa digresión - son los primeros que la escritura del archivo oblitera. Las lacónicas noticias necrológicas que le dedicó la prensa oficial en Buenos Aires, ricas en hechos que no en espíritu, atestiguan esa tendencia a matar con la letra. Nos dan un chato itinerario vital (crítico destacado, colaborador y jefe de redacción de la revista Sur, ejemplar profesor del Instituto Superior del Profesorado y de la Facultad de Filosofía y Letras, notable traductor, sabio asesor de la Editorial Sudamericana, etc. etc.) pero poco nos dicen de Pezzoni. Por cierto no nos dan con qué recordarlo.

La levedad, la ironía, el humor, escasean en nuestras letras, para no hablar de nuestra crítica. En Pezzoni, eran -más allá de la amabilidad--instrumentos profesionales de crítico y maestro, medios de indagación que culminaban en la iluminación pero también en la inquietud fecunda. Lo preparaban para la tarea más ardua: la de leer, y leer con otros, la multiplicidad de voces que es un texto. No por azar le interesaban los escritores argentinos del Ochenta, a los que dedicó más de un artículo. Intuía en ellos, más allá de los lazos de clase y la satisfacción ideológica que parecen unirlos, más allá de la soltura oral que, como conversador ejemplar, sin duda admiraba, una tenaz preocupación por la literatura con la que se identificaba:

[A]cude una y otra vez a la literatura, insistente y ambiguo, como en un asedio amoroso que le impusiera un abundante repertorio de estrategias para seducir. Corroborar ese apremio y esa multiplicidad de actitudes sin ir más lejos, aplaudírselas o perdonárselas es leerlo por encima o desde lo que sobre él han acumulado los manuales. En todo caso, es no percibir el interrogante que sus textos plantean al lector y se plantean a sí mismos (sin formularlo claramente, desviándolo por el atajo de la broma o la ocurrencia) en cuanto a lo que la literatura es y a lo que dentro, desde ella puede hacerse con el mundo. En esta perspectiva, el juicio de valor se desplaza desde la comprobación de la gracia [...] hacia el testimonio de ese obstinado y tácito reflexionar sobre la literatura que trasciende de sus páginas. No tanto de cada una de ellas, cuanto de su conjunto. En la relectura [...], el fragmentarismo se recompone en líneas coincidentes; la dispersión se vuelve figura -obsesión-central.

El texto de Pezzoni se refiere a Eduardo Wilde. ¿O se refiere a Enrique Pezzoni? "El crítico-nos advierte en el prólogo a El texto y sus voces-compone la biografía de la literatura, que es su autobiografian. De hecho, ese reflexionar sobre la literatura desde el fragmentarismo, la dispersión, lo inconexo, signa la obra de los escritores que, para usar un verbo que aparece con frecuencia en el texto de Pezzoni, más lo sedujeron: escritores tan variados (y en algún plano unidos) como Felisberto Hernández, Silvina Ocampo, Alberto Girri, Alejandra Pizarnik, y desde luego Borges. "No hay aquí hueco central que llenar, no hay conjunto: lo que debemos aprehender es el valor de cada parte. Este fluctuar de visiones que se suceden sin que la mirada se pose al fin en una, escogida como 
'verdadera', no puede interpretarse como la angustia de una elección imposible. Es, al revés, el embeleso de quien siente que lo revelado es esto y también lo otro", escribe de Alejandra Pizarnik. O de sí mismo.

El ser esto y también lo otro, la tendencia a irradiar más que a concentrarse, la sabiduría (la valentía, también) de reconocerse, como Truman Capote, en un "radiante oxímoron, negro espejo hecho añicos, caleidoscópica imagen del que se busca a sí mismo", no lo paralizaron. Durante años, fue una de las presencias críticas más apasionadas y más lúcidas de la Argentina. Fue también un eximio traductor, y no sólo de textos: su presencia fue un puente, estableció nexos, incluso diálogos, entre grupos intelectuales diversos que, sin él, no se habrían comunicado. El ser esto y también lo otro no le impidió tampoco tomar valientes decisiones que, sobre todo en su gestión le ganaron duras críticas. Acaso le haya impedido, sí, escribir(se) de manera más consecuente, anotar sus irradiaciones para lectores futuros, economizarse. En cambio, derrochaba esas irradiaciones con amigos, con discípulos, con desconocidos, en una deslumbrante performance donde la anécdota elocuente resultaba ejercicio crítico, apuntalado por una autoironía continua. Porque, no hay que olvidarlo, fue uno de los narradores más diestros de la Argentina, autor de un vastísimo e inasible relato oral, un autobiógrafo que desplegaba magistralmente ante su público sus memorias etéreas y les daba provisoria vida en el lugar común de su voz, hoy irreproducible.

La última vez que vi a Enrique Pezzoni en Nueva York estaba ya enfermo aunque no parecía saberlo. Fuimos con amigos a ver uno de los espectáculos que más solían divertirlo en esta ciudad, el Ridiculous Theatre de Charles Ludlum. La representación nos desencantó, acaso porque fuera mala, acaso purque se sentía la ausencia de Ludlum, muerto recientemente como moriría, poco después, el propio Enrique. La sensación de final de fiesta que tuve entonces se reprodujo con tanta más intensidad en Buenos Aires, a los pocos meses de su muerte. Sentí la falta de Pezzoni individualmente pero también la sentí en los otros, en los muchos amigos que me hablaron de él, que necesitaban hablar para recordarlo y recordarse en él. Creo que nos vemos más a menudo desde que se murió, me dijo alguien. Pero nadie cuenta los cuentos. 
